\title{
Effect of Polybrominated Biphenyls on the Accumulation of DNA, RNA, and Protein in Cultured Rat Embryos following Maternal Administration
}

\author{
D. L. FISHER \\ Department of Anatomy, University of Michigan, Ann Arbor, Michigan 48109
}

Received March 10, 1980

\begin{abstract}
Using a system of whole-embryo culture, the effect of polybrominated biphenyls (PBB) was investigated on the rates of DNA, RNA, and protein accumulation in rat embryos. Embryos were isolated on the 10th gestational day (sperm day = Day 0) either 4 or $24 \mathrm{hr}$ after maternal administration. The cultivation period was for 24 or $42 \mathrm{hr}$. DNA, RNA, and protein accumulation rates were not affected by a 4-hr previous maternal administration either at the beginning or following cultivation. At the beginning of cultivation for embryos exposed to PBB $24 \mathrm{hr}$ before dissection, there was a significant reduction in DNA and total embryonic protein but RNA values were not affected. At $24 \mathrm{hr}$ cultivation, protein values were no longer significantly different. DNA values remained significantly lower throughout culture. The significant anatomical differences noted at $24 \mathrm{hr}$ cultivation were: (i) a failure of neuropore closure; (ii) a retention of a dorsiflexed position; (iii) a retardation in somite development; (iv) a reduced number with anterior limb buds present; (v) a reduction in the number establishing a visceral yolk sac circulation; and (vi) a decreased heart rate. After 42 $\mathrm{hr}$ in culture, the only significant anatomical differences were a reduction in the number of embryos developing anterior limb buds and a decrease in the number of somites added. It is concluded that the major embryonic effects of PBB for the first $24 \mathrm{hr}$ after administration appear to be transitory if the embryo is removed from the exposure environment.
\end{abstract}

\section{INTRODUCTION}

With the event of mixing polybrominated biphenyls (PBB) accidently with livestock feed in Michigan, the effects of this chemical on the consuming population became of paramount importance. The contaminated feed was consumed by a large number of farm animals and became irreversibly incorporated into meat and milk. In a dairy herd a toxic syndrome attributed to PBB has been described (Jackson and Halbert, 1974). Symptoms were manifest as anorexia and a dramatic fall in milk production. Necropsy findings reported liver lesions as the most consistent pathologic finding. Embryotoxicity was also suspected but not confirmed. Evidence for embryotoxicity in rodents has been established (Corbett et al., 1975) as well as recent evidence for teratogenicity (Beaudoin, 1977). Liver changes have also been reported in quail and sheep (Babish et al., 1975). The accumulation of PBB in adipose tissue has been established (Fries et al., 1975) and it appears in the milk of the lactating cow (Fries and Marrow, 1975; Prewitt et al., 1975). PBB has also been shown to cross the placenta in cows (Detering et al., 1975) as well as in rats (Corbett et al., 1975).

The present investigation was designed to determine: (1) a preliminary delimitation of embryo exposure time required for PBB to exert a teratogenic response; (2) the effects PBB may have on total embryonic protein, DNA, and RNA pro- 
duction; and (3) as observed with trypan blue, ATDA, and sodium arsenate experiments (Beaudoin and Fisher, 1980) if embryonic recovery from damage involves a fetal-maternal interaction. To test these, embryos were removed from the uterus 4 and $24 \mathrm{hr}$ after maternal gavage administration of PBB and cultured for 24 to $42 \mathrm{hr}$.

\section{MATERIALS AND METHODS}

\section{Morphologic Procedures}

Wistar derived rats maintained in our laboratories were fed Teklad Rat Diet (Teklad Mills, Winfield, lowa) and water ad libitum with lettuce supplemented weekly. Temperature was from 70 to $72^{\circ} \mathrm{F}$ with a 14-hr light cycle maintained throughout. A single male was placed with three to six females $(\sim 150 \mathrm{~g})$ in the evening and vaginal sperm checked the following morning. The discovery of sperm was designated Day 0 of pregnancy.

The PBB mixture used in this experiment was the commercial preparation Firemaster BP-6 (Michigan Chemical Co., St. Louis, Mich.) at $800 \mathrm{mg} / \mathrm{kg}$. Solutions of PBB were prepared in sesame oil and administered by gavage either 4 or $24 \mathrm{hr}$ before dissection on Day 10. Control animals were either sham fed with the vehicle or not fed. As no significant differences were noted between the results of the two methods for control embryos, results were pooled.

Dissection was according to the method of New and Coppola (1977). At this time, the embryos: are normally five to nine somites; are dorsiflexed; have neuropores open; have limb buds absent; and do not have a visceral yolk sac circulation. Cultivation conditions followed the method of Kochhar (1975) using 50\% Waymouth's medium (GIBCO, Grand Island, N.Y.) and $50 \%$ fetal calf serum (GIBCO). The Waymouth's medium was supplemented with 5000 units/liter penicillin and $5000 \mu \mathrm{g} /$ liter streptomycin. Embryos with the visceral yolk sac intact were individually placed in $10-\mathrm{ml} \mathrm{screw}$-top plastic tubes containing $1.5 \mathrm{ml}$ of medium maintained at $37^{\circ} \mathrm{C}$ and rotated on a mechanical rotator at $30-40 \mathrm{rpm}$. The gassing sequence used was that suggested by New and Coppola (1977) beginning with $10 \% \mathrm{O}_{2}, 5 \% \mathrm{CO}_{2}$, and $85 \% \mathrm{~N}_{2}$. The $\mathrm{O}_{2} \%$ was increased every $12 \mathrm{hr}$ to 20,50 , and $80 \%$. Nitrogen was decreased concomitantly. The $5 \% \mathrm{CO}_{2}$ was held constant for stabilization of $\mathrm{pH}$. The embryo culture was either terminated after $24 \mathrm{hr}$ or the embryos were transferred to fresh medium and cultivation continued until $42 \mathrm{hr}$. At least five separate experimental trials for each 4- and 24-hr exposure were made using a total of 26 dams and 190 cultivated embryos.

\section{Analytic Methods}

1. Gross anatomical parameters. At termination of cultivation, at $24 \mathrm{hr}$, or 42 $\mathrm{hr}$, a number of developmental parameters were analyzed. Growth in size and shape were selectively made by photographic measurements. Heart rate was timed by stopwatch for $15 \mathrm{sec}$ at $37^{\circ} \mathrm{C}$. Somite numbers were counted. Subjective comparisons of treated and nontreated embryos were made for: closure of the anterior neuropore; rotation to a ventroflexed position; indication of anterior limb bud swellings; establishment of visceral yolk sac circulation; fusion of the amni- 
otic and allantoic sacs; and presence or absence of an edematous condition in the pericardial sac or ventricles of the brain.

2. Protein analysis. Analysis followed the method of Lowry et al. (1951). At 0 and $24 \mathrm{hr}$ the homogenate of one embryo was used for analysis. At $42 \mathrm{hr}$ the homogenate could be diluted by one half.

3. DNA and RNA analysis. Analysis was by the ethidium bromide fluorometric technic of Prasad et al. (1972) as modified by Dr. E. Ritter (personal communication, 1978). The spectrophotofluorometer excitation wavelength was $365 \mathrm{~nm}$ and emission wavelength was $590 \mathrm{~nm}$. Analysis was made at 0,24 , and/or $42 \mathrm{hr}$ for each experiment.

4. Statistical analysis. A multiple linear regression analysis was used with $P$ values less than 0.05 indicating a level of significance. The Student $t$ test was used for comparisons between the treated and nontreated embryos. An analysis of variance and Dunnett's $D$ statistic were also compared. The correlation coefficients of linearized standard curves were all greater than $r=0.98$.

\section{RESULTS}

\section{Gross Anatomical Differences}

For those embryos exposed in utero $24 \mathrm{hr}$ prior to dissection after $24 \mathrm{hr}$ in culture, the major differences include a significant number of embryos failing to: rotate to a ventroflexed position; retain an open anterior neuropore; develop anterior limb buds; develop a visceral yolk sac circulation; and develop the control complement of somites. By $\mathbf{4 2} \mathrm{hr}$ in culture, the only significant differences remained a reduction in the number of embryos developing anterior limb buds and a decrease in the number of somites added.

For those embryos exposed in utero $4 \mathrm{hr}$ prior to dissection, after $24 \mathrm{hr}$ in culture there was a significant number of embryos failing to rotate to a ventroflexed position as well as a significant number of embryos retaining an open anterior neuropore. By $42 \mathrm{hr}$ in culture the only remaining significant difference was reduction in the number rotating to a ventroflexed position (Fig. 1).

Somite additions for embryos exposed to PBB in utero $24 \mathrm{hr}$ prior to dissection were $7.2 \pm 0.8,16.2 \pm 0.8^{*}$, and $21.6 \pm 0.7^{*}$ at 0,24 , and $42 \mathrm{hr}$ of culture, respectively (asterisk indicates statistically significant reduction from control levels). Concomitant controls were 7.8 $\pm 0.5,19.0 \pm 1.0$, and $24.8 \pm 0.5$ for the same cultivation period. The percentage of embryos developing a visceral yolk sac circulation after $24 \mathrm{hr}$ in culture, having been exposed in utero to PBB $24 \mathrm{hr}$ prior to dissection, was also significantly lower than control levels at $59 \pm 6.4 \%$. Concomitant controls were $81.9 \pm 4.7 \%$. (Other significant statistics are presented elsewhere-Beaudoin and Fisher, 1980.)

\section{Biochemical Differences after in Utero Exposure to PBB prior to Dissection}

The multiple regression analysis used showed no significant biochemical difference in DNA, RNA, or protein content for those embryos exposed in utero $4 \mathrm{hr}$ prior to dissection. For embryos exposed in utero $24 \mathrm{hr}$ prior to dissection a significant reduction in protein and DNA content was noted at the beginning of 


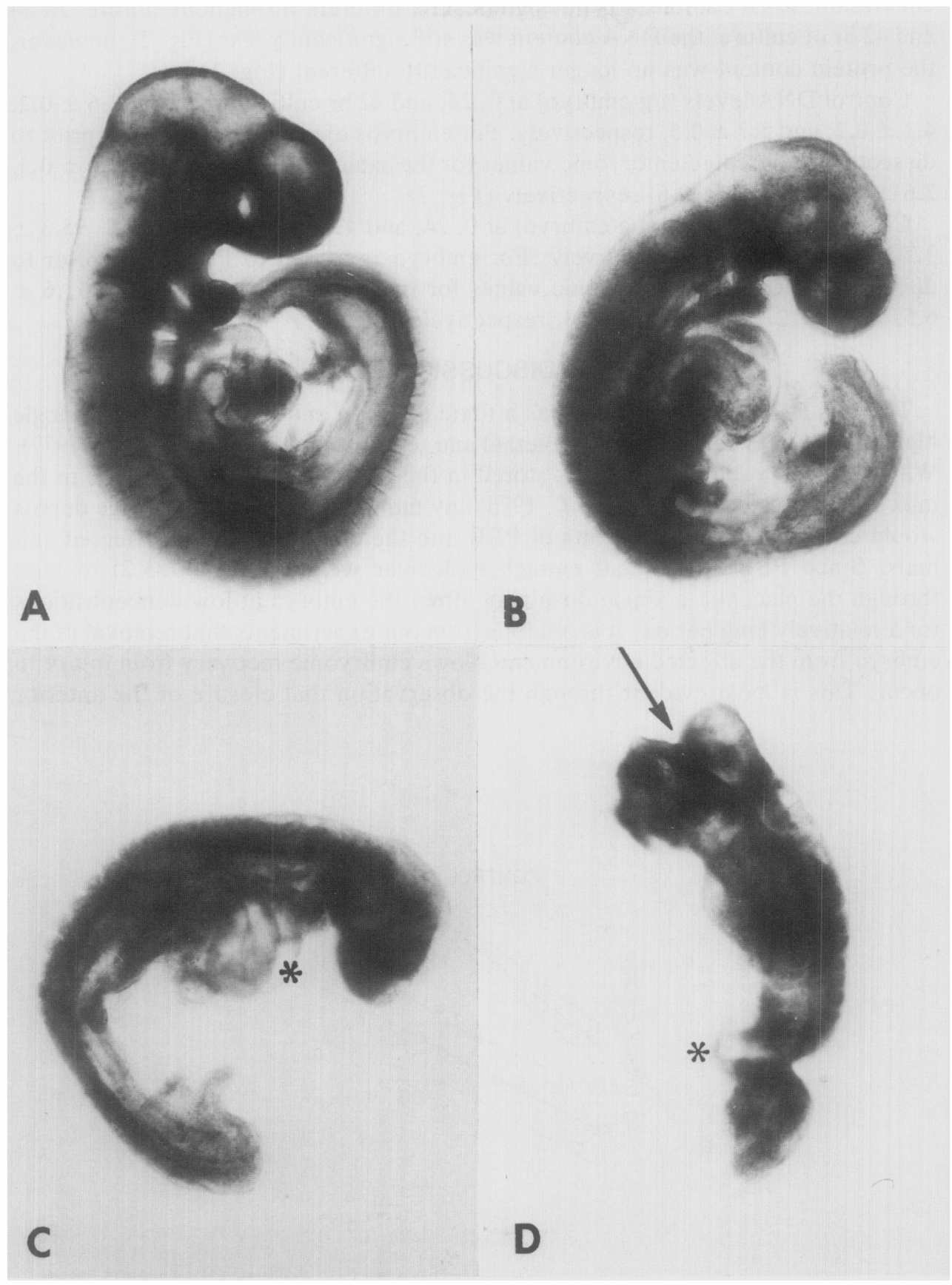

FIg. 1. Effects of PBB on embryonic development after maternal administration $24 \mathrm{hr}$ prior to dissection. (A) control embryo after $24 \mathrm{hr}$ cultivation. (B) embryo from PBB in utero treatment $24 \mathrm{hr}$ prior to dissection. Note decrease in size and development. (C) Embryo treated as in B. Asterisk indicates pericardial edema. Note also the absence of anterior limb buds. (D) Embryo treated as in B. Arrow indicates open anterior neuropore. Asterisk indicates retained ventroflexed position. 
cultivation. RNA content was not significantly different throughout culture. At 24 and $42 \mathrm{hr}$ of culture, the DNA content was still significantly less (Fig. 2), however, the protein content was no longer significantly different (Fig. 3).

Control DNA levels ( $\mu \mathrm{g} / \mathrm{embryo}$ ) at 0,24 , and $42 \mathrm{hr}$ cultivation were: $2.6 \pm 0.2$, $4.1 \pm 0.2$, and $5.7 \pm 0.5$, respectively. For embryos exposed to PBB $24 \mathrm{hr}$ prior to dissection, the treated embryonic values for the same time period were: $2.0 \pm 0.3$, $2.6 \pm 0.3$, and $3.3 \pm 0.6$, respectively (Fig. 2 ).

Control protein levels ( $\mu \mathrm{g} / \mathrm{embryo}$ ) at 0,24 , and $42 \mathrm{hr}$ were: $48.4 \pm 3.1,95.3 \pm$ 3.7 , and $158 \pm 10.9$, respectively. For embryos exposed to PBB $24 \mathrm{hr}$ prior to dissection, the treated embryonic values for the same time period were: $31.6 \pm$ $6.5,78.4 \pm 12.7$, and $155 \pm 44.3$, respectively (Fig. 3).

\section{DISCUSSION}

There is little doubt that PBB has a toxic effect in animals. In the rat, a single high dose of PBB can have embryolethal and teratogenic effects (Beaudoin, 1977). With the observation that PBB is stored in the adipose tissue and appears in the milk of lactating cows (Fries et al., 1975) any mobilization of these storage depots would continually bring amounts of PBB into the circulation of the affected animals. Since PBB is of small enough molecular weight (548.5-785.2) to pass through the placenta, a single dose may affect the embryo at low concentrations for a relatively long period. It is obvious from our experiments that removal of the embryo from the affected environment allows embryonic recovery from injury to occur. This is most evident through the observation that closure of the anterior

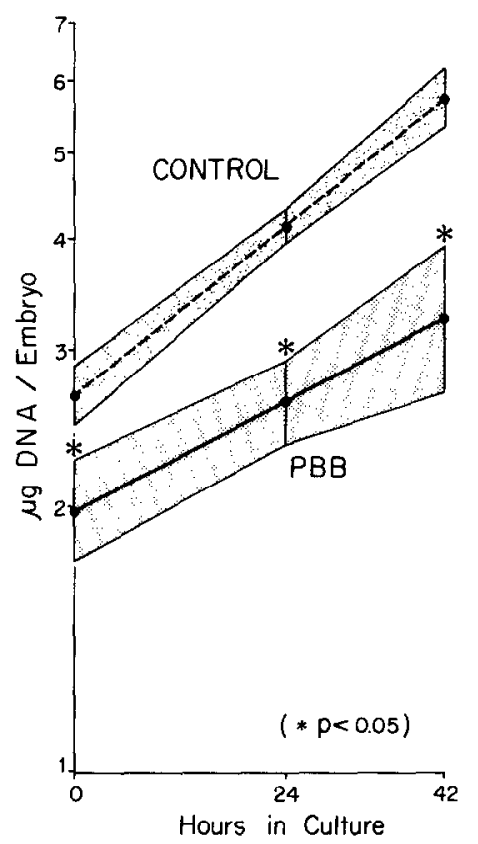

Fig. 2. Effects of PBB on DNA accumulation in the embryo over the cultivation period following in utero exposure $24 \mathrm{hr}$ prior to dissection. Grouped by mean and standard error of slope and intercept. 


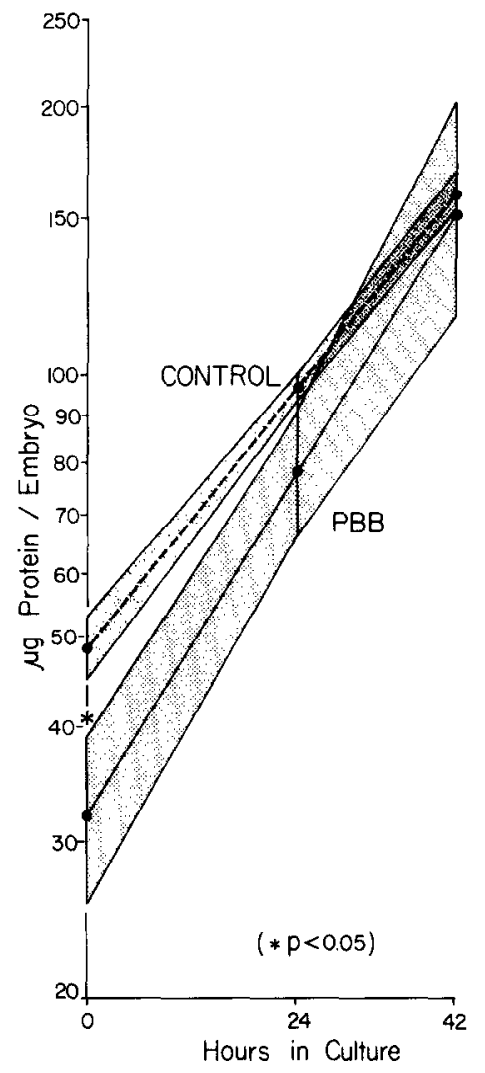

Fig. 3. Effects of PBB on protein accumulation in the embryo over the cultivation period following in utero exposure $24 \mathrm{hr}$ prior to dissection. Grouped by mean and standard error of slope and intercept.

neuropore is impaired but not inhibited. Also, the initial decrease in protein content observed after the embryo was exposed in utero for $24 \mathrm{hr}$ was eliminated after removal and $24 \mathrm{hr}$ cultivation. The decrease in total DNA present at the beginning of cultivation was not overcome by the embryo, however, during the cultivation period. The slopes of the two lines in Fig. 2 are not significantly different. Degradation of existing DNA and the reformation of new DNA may be occurring due to insult, but the method used allows no demonstration of this and deserves further study. It is best concluded from the present observations that removal of the embryo from the affected environment allows recovery from injury to occur with development proceeding at a normal but asynchronous level. An in utero exposure $4 \mathrm{hr}$ prior to dissection appears to place some transitory effects on morphologic development, but biochemical differences, for the parameters used, were not detectable.

It is obvious that a number of questions regarding the embryonic effects of PBB remain unanswered. Does PBB (1) pass from the mother, accumulate, have a direct effect and remain in fetal tissues; (2) cross the placenta, exert its harmful effects in the fetus, and decompose or otherwise become inactive; (3) effect the embryo as a maternal metabolite; or (4) remain in the mother or placental tissues 
and exert its embryotoxic effects indirectly by disrupting some function in the placenta or maternal system? The answers to these questions demand further investigation.

It can be postulated from the observations made, however, that if it were possible to remove $\mathrm{PBB}$ from the embryonic environment within a 24 -hr period, the effects exerted would be of a transitory nature. The possible exception would be a delay in overall developmental rate.

\section{ACKNOWLEDGMENTS}

I wish to thank Dr. A. R. Beaudoin for assistance and advisement and Francine Hale for skilled technical assistance. This work was supported by an Environmental Protection Agency Grant issued to Dr. A. R. Beaudoin.

\section{REFERENCES}

Babish, J. G., Guntemann, W. H., Lish, D. J., and Stoewsand, G. S. (1975). Liver changes and tissue residues of animals fed hexabromobiphenyl. Fed. Proc. 34, 157.

Beaudoin, A. R. (1977). Teratogenicity of polybrominated biphenyls in rats. Environ. Res. $14,81$.

Beaudoin, A. R., and Fisher, D. L. (1980). An in vivo/in vitro evaluation of teratogens. Teratology, in press.

Corbett, T. H., Beaudoin, A. R., Cornell, R. G., Anver, M. R., Schumacher, R., Endres, J., and Szwabowska, M. (1975). Toxicity of polybrominated biphenyls (Firemaster BP6) in rodents. Environ. Res. 10, 390.

Detering, C. N., Prewitt, L. R., Cook, R. H., and Fries, G. F. (1975). Placental transfer of polybrominated biphenyl by Holstein cows. J. Dairy Sci. 58, 764.

Fries, G. C., and Marrow, G. S. (1975). Excretion of polybrominated biphenyls into the milk of cows. J. Dairy Sci. 58, 947.

Fries, G. F., Marrow, G. S., Detering, C. N., Prewitt, L. R., and Cook, R. M. (1975). Distribution of polybrominated biphenyl residues in tissues of dairy cattle. J. Dairy Sci. 58, 764.

Jackson, T. F., and Halbert, F. L. (1974). A toxic syndrome associated with the feeding of polybrominated biphenyl contaminated protein concentrate to dairy cattle. J. Vet. Med. Assoc. 165, 437.

Kochhar, D. M. (1975). The use of in vitro procedures in teratology. Teratology 11, 273.

Lowry, O. H., Rosebrough, N. J., Farr, A. L., and Randall, R. J. (1951). Protein measurement with the Folin phenol reagent. J. Biol. Chem. 193, 265.

New, D. A. T., and Coppola, P. T. (1977). Development of a placental blood circulation in rat embryos in vitro. J. Embryol. Exp. Morphol. 39, 229.

Prasad, A. S., DuMouchelle, E., Koniuch, D., and Oberleas, D. (1972). A simple fluorometric method for the determination of RNA and DNA in tissues. J. Lab. Clin. Med. 80, 598.

Prewitt, L. R., Cook, R. M., and Fries, G. F. (1975). Field observations of Michigan dairy cattle contaminated with polybrominated biphenyl. J. Dairy Sci. 58, 763.

Ritter, E. (1978). RNA and DNA determination on 10- and 11-day rat embryos. Personal communication. 